\title{
What is it like to be an indigenous student of business administration?
}

\author{
Renan Carlos KLICHOWSKI ${ }^{1}$ \\ MARCIO PASCOAL CASSANDRE ${ }^{1}$ \\ WAGNER ROBERTO DO AMARAL ${ }^{2}$ \\ 1 Universidade Estadual de Maringá (UEM) / Programa de Pós-graduação em Administração, Maringá - PR, BraziL \\ 2 Universidade Estadual de Londrina (UEL) / Programa de Pós-Graduação em Política Social e SerVIÇO SOCIAL, LONDRINA - PR, BRAZIL
}

\begin{abstract}
Higher education programs in Brazil, especially those in business administration, have been historically established and designed by the upper classes for their political and developmentalist interests. The affirmative action of reserving places for indigenous people in the Brazilian public universities - such as in the case of the state universities of Paraná, from 2001 - became an important novelty. This policy, however, has been criticized by indigenous students given the existing barriers in the educational structure, which disregards dilemmas experienced by these students in their ethnic-community and academic spaces. The objective of this study is to identify and analyze the understandings, expectations, and dilemmas present in the educational paths of indigenous students enrolled in administration programs in the state universities of Paraná, Brazil. The testimony strategy was used to understand and analyze the educational experiences of indigenous students. The research indicated what it is like to be an indigenous higher education student of administration in the academic and ethnic-community spaces, besides pointing out anxieties regarding the world of work as indigenous administrators.
\end{abstract}

Keywords: Indigenous student. Indigenous peoples. Double Belonging. Administration. Testimony.

\section{O que é ser um acadêmico indigena de administração?}

\section{Resumo}

Historicamente, a educação superior, em especial nos cursos de administração no Brasil, foi criada e aperfeiçoada pelas classes dominantes e seus interesses políticos e desenvolvimentistas. As iniciativas de reserva de vagas para indígenas estudarem nas universidades públicas brasileiras, como no caso das universidades estaduais do Paraná, a partir de 2001, passaram a ser uma novidade questionada por esses estudantes, por meio de barreiras levantadas na estrutura educacional não contemplativas do chamado pertencimento étnico-comunitário e acadêmico dos estudantes. O objetivo geral deste estudo é identificar e analisar quais as compreensões, expectativas e os dilemas presentes nos percursos formativos dos estudantes indígenas dos cursos de administração das universidades estaduais paranaenses. Em busca desse conhecimento, a história de vida, por meio da estratégia do testemunho, foi utilizada para compreender e analisar as experiências dos indígenas relativas aos seus percursos formativos. A pesquisa indicou pistas do que é ser um acadêmico de administração indígena no espaço acadêmico e étnicocomunitário, além de apontar anseios com relação ao mundo do trabalho. Teoricamente, o estudo trouxe uma perspectiva mais restrita ao duplo pertencimento, saindo de uma visão macro.

Palavras-chave: Estudante indígena. Universidade. Duplo pertencimento. Administração. Testemunho.

\section{¿Qué es ser un académico de administración indigena?}

\section{Resumen}

Históricamente, la educación superior, especialmente en la carrera de administración en Brasil, fue creada y perfeccionada por las clases dominantes, por sus intereses políticos y de desarrollo. Las iniciativas de reserva de vacantes para que indígenas estudien en las universidades públicas brasileñas, como en el caso de las universidades públicas del estado de Paraná a partir del año 2001, pasaron a ser una novedad importante pero cuestionada por los estudiantes indígenas, debido a las barreras planteadas en la estructura educativa brasileña que no contempla la denominada pertenencia étnico-comunitaria y académica de los estudiantes. El objetivo general de este estudio es identificar y analizar cuáles son las interpretaciones, expectativas y dilemas presentes en los itinerarios formativos de los estudiantes indígenas de los cursos de administración de las universidades públicas del estado de Paraná. En busca de ese conocimiento, se recurrió a la historia de vida por medio de la estrategia del testimonio- para comprender y analizar las experiencias de los indígenas con relación a su recorrido formativo. La investigación dio indicios de lo que es ser un estudiante indígena de administración en el espacio académico y étnico-comunitario, así como señaló anhelos con respecto al mundo del trabajo. Teóricamente, el estudio aportó una perspectiva más restringida a la doble pertenencia, al eximirse de una visión macro.

Palabras clave: Estudiante indígena. Universidad. Doble pertenencia. Administración. Testimonio. 


\section{INTRODUCTION}

Since the history of the contact with Europeans, the relationship between indigenous people and the Brazilian State has remained conflicted, taking in consideration that the Brazilian State typically represented the interests of the nobility, the elite and the bourgeoisie, whether in the colonial period, in the empire, in the republic or in the dictatorship (PACHECO DE OLIVEIRA and FREIRE, 2006; CARVALHO, 2013). In more recent times, marked by the democracy, at the end of the 1980s, the struggles and conquests achieved by the indigenous populations can be seen in the resumption and demarcation of their traditional territories, in the demands for public policies along with the State, as well as in the clashes over spaces that were little occupied by them, such as universities, and in the State structure itself (AMARAL, 2010; CARVALHO, 2013).

One of the important achievements was the recognition of Indigenous School Education as a specific modality of basic education in Brazil, through the Law of Directives and Bases of National Education, of 1996 (CAPELO and TOMMASINO, 2004; PACHECO DE OLIVEIRA and FREIRE, 2006; AMARAL, 2010; AMARAL, RODRIGUES and BILAR, 2014). The expansion of the offer of specific, intercultural, bilingual and community basic education for indigenous populations has made possible the simultaneous and progressive demand of young indigenous people for higher education in the last two decades in Brazil. In this context, in the state of Paraná, the Law No. 13,134/2001 was recognized as another achievement for the indigenous people, which had guaranteed additional places in the state universities of Paraná. The fact is that the pioneering spirit of these and other public universities in Brazil legitimizes the academic knowledge produced by the indigenous people in these educational institutions, which can become a significant strategy for the cultural and political affirmation of indigenous peoples (AMARAL, 2010; AMARAL, RODRIGUES and BILAR, 2014).

However, when carrying out investigations about the trajectories of indigenous scholars, Amaral (2010) finds that a "double belonging" necessarily marks their entry into public higher education. As the author conceptualizes, this conjuncture demands, from these new students, an articulation between two belongings: ethnic-community belonging and academic belonging. Ethnic-community belonging involves knowledge, specific rules, customs, traditions, culture and the full range of specific characteristics of different indigenous peoples and their communities, to which indigenous students are attached.

Academic belonging, on the other hand, requires the student to correspond to the norms and rules of the higher education institution, historically developed through non-indigenous and capitalist logics in Brazil. At the same time, such belonging exposes the student to all possibilities of perversities, exclusions, conflicts, interculturalities, knowledge and affirmation that they can find in this space (AMARAL, 2010). In this way, indigenous students need to deal, in the academic experience, with double belonging, a characteristic that directly influences the constitution of new professional categories, including indigenous people in existing categories, such as administrators, educators and doctors (AMARAL, 2010; AMARAL, RODRIGUES and BILAR, 2014).

In order to identify how studies that reflect the thematic of indigenous higher education and, in particular, indigenous higher education in administration, in Brazil and abroad, a bibliographic review was carried out on the Spell and ProQuest platforms, without any temporal restrictions. In the national research base, 24 articles were found, of which only 1 discusses indigenous higher education. In the international database, ProQuest, 23 articles were found from eight different countries, of which 12 are related to indigenous higher education and another six are related to intercultural education. Thus, it was found that there are few studies related to indigenous higher education (in these databases), as indicated by studies by some authors about the topic (AMARAL, 2010; AMARAL, RODRIGUES and BILAR, 2014; CASSANDRE, AMARAL and SILVA, 2016; ANGNES, FREITAS, KLOZOVSKI et al., 2017; AMARAL, FRAGA and RODRIGUES, 2016).

According to data provided by the University Commission for the Indigenous of Paraná, of the 163 indigenous people enrolled in Paraná state universities at the beginning of the 2017 academic year, seven were enrolled in the administration course, but during the same year, three of them dropped out. Thus, four indigenous students remain enrolled in administration in that year.

In view of the context of entry and permanence of indigenous students in state universities in Paraná, this article aims to identify and analyze the understandings, expectations and dilemmas present in the formative path of indigenous students in the administration courses of Paraná state universities. 
It is noteworthy that the initiatives carried out by Brazilian universities and, differently, by the government of the state of Paraná, put into practice in the 2000s, and in 2012 in federal higher education institutions (HEls), are recent, considering the 518 years of contact between indigenous and non-indigenous societies in the Brazilian territory. Therefore, the emergence of indigenous professionals and, in particular, indigenous administrators is a novelty that needs to be referred to in order to open a critical field of evaluations and proposals for educational institutions, for contracting organizations and for indigenous and non-indigenous societies. In this sense, the present study is relevant because it is a reference source for expanding discussions in the administration area, innovative for organizational studies, especially with regard to discussions about diversity in organizations.

\section{METHODOLOGICAL PATH}

In the first moment of the research, secondary data were collected in scientific publications, articles, printed materials, books, public archives, private archives, statistical sources, among others. It also was used information available in the 2010 Demographic Census, on the online website of the National Foundation of the Indigenous (FUNAI) ${ }^{1}$, and in Pacheco de Oliveira and Freire (2006). The data and information were reproduced in this research also in a secondary way, without new statistical treatments.

Subsequently, after collecting bibliographic data, in the Spell (national) and ProQuest (international) databases, as a way of listening to the students' perception, with the intention of using an epistemological perspective that represents the research subjects and "overcoming invisibility of indigenous peoples" (AMARAL, 2010, p. 153), testimony was used as a strategy to the approach of life history, a qualitative technique that allowed the identification of the subject's personal experience - in this case, the indigenous student (BERNAL, BURCIAGA and CARMONA, 2012).

In this phase of contact with indigenous students, it was elaborated a semi-structured script to assist the interviewer, serving as an accessory tool for the development of the listening of the testimonies. This script was divided into three parts: a) identification of respondents; b) trajectories at the university; and c) trajectories and expectations about the world of work.

In this research, all indigenous students enrolled in the administration courses of Paraná state universities accepted, after previous contact, to contribute with their testimonies that were recorded in audio, transcribed and organized in written text. The collection of testimonies took place individually, without the participation of third parties, or interruptions during the conversation. The audio recording served for individuals to feel more at ease, with a minimum of formality and without intervention by the interviewer, as a way of maintaining distance. Thus, the stories were told by the students in a way that it was personal and free.

At the end of each testimonial approach, a few hours later, the interviewer transcribed each testimony literally. In the following day, the texts were sent to the indigenous students electronically (WhatsApp and e-mail) to confirm what they had said. In all cases, the students returned on the same day, with only corrections related to personal and place names. In order to keep the identity of the participants confidential, their names were replaced by other names of indigenous origin: Yara, Niara, Ubirajara and Raoni.

In this article, a synthesis of the testimonies is presented, evidencing perceptions and indications about the thematic, combined with elements exposed throughout this article, explaining what can be understood in the three themes that were addressed. The testimonies were not reproduced in this publication due to the question of space and number of words, but, in any case, essential passages were brought to understand the synthesis.

Based on the understanding and clarification of the methodological path taken in this research work, below, there is a space in the article for the empirical-theoretical understanding related to the double belonging.

${ }^{1}$ Data consulted at the online address of the National Foundation of the Indigenous (FUNAI), available at: <http://www.funai.gov.br/index.php/indios-nobrasil/quem-sao>. Accessed on June/2017. 


\section{The double belonging from the macro point of view}

The access of indigenous people in the state universities of Paraná, according to Amaral (2010), provokes, in the indigenous student, the experience of an arduous process. In this process, these students need to deal with values present in indigenous and non-indigenous societies, the latter being fundamentally urban. At the same time, indigenous students experience double belonging, a new process for the universities, for the original communities and for the urban societies, especially for these subjects.

When analyzing the paths of indigenous students in the public higher education in Paraná, Amaral (2010) reflects the phenomenon of double belonging, showing and arguing that the permanence of indigenous people in the state universities of Paraná (from the Vestibular of Indigenous Peoples) is only possible when these subjects manage to "constitute and maintain their identity as an indigenous university student, demanding from this subject the simultaneous support of their academic and ethnic-community belonging" (AMARAL, 2010, p. 510).

This situation, according to Amaral (2010), Angnes, Freitas, Klozovski et al. (2017) and Amaral, Fraga and Rodrigues (2016), is the result of claim struggles initiated by indigenous movements and organizations that sought to institutionalize indigenous schools with the guarantee that basic education would promote the "principles of bilingualism, specificity and interculturality" (as provided and regulated by law). Higher education started to be strongly guided by indigenous and indigenist organizations as an alternative and strategy for training and enabling indigenous teachers to work in schools created within indigenous lands (AMARAL, 2010, p. 66).

The fact is that the originality assumed by the state universities of Paraná, and by other public universities in Brazil, in the same decade, starts to express that the academic knowledge produced by the indigenous people themselves in public universities has become a strong strategy of cultural and political affirmation of these peoples (AMARAL, 2010). However, according to Amaral (2010), Angnes, Freitas, Klozovski et al. (2017) and Amaral, Fraga and Rodrigues (2016), the entry and permanence of indigenous people in universities and in the urban spaces that are little frequented by them in daily basis evidences the challenge of exchanging different conceptions, experiences and perspectives, which causes them to reflect about their ethnic identities.

When synthesizing the conceptual analysis reflected by Amaral (2010), three significant categories are identified and guide his thesis: 1) academic belonging, characterized in addition to a formal enrollment, linked to the processes experienced by indigenous people in their academic dimension, having in view their stay at the university as a student; 2) ethnic-community belonging, corresponding to their socio-cultural origins, aspects of their ethnic identity, their community ties, among others; and 3) double belonging, which brings together and manifests the associations and tensions of the two belongings.

An ethnic group is not a closed and static group; the ethnic belonging, the identity and the culture are dynamic and negotiable, according to Barth (1998). The concept of ethnic group can be understood as a social organization "that has a group of members that identifies itself and is identified by others as if it constituted a differentiable category from other categories of the same type" (BARTH, 1998, p. 190-193).

When different groups come into contact, frictions, manifestations, cultural changes occur, in which ethnic boundaries are exposed. According to Barth (1998), ethnic boundary is understood as the manifestation highlighted in the relationship of different people and groups, explaining persistence and changes in rules and cultural traits expressed by the adoption of an identity, exclusion or inclusion of a member to a group.

In other words, an ethnic border is the contrast of one ethnic group with another, as a way of defending a group or manifesting inclusion and change. Barth (1998) adds that, whether consciously or not, an individual acts in the dynamics of his ethnic identity or the ethnicity of his group. A large part of an apprehended ethnic identity is unconscious and incorporated since the subject's birth, constituted in a relational way, always under construction.

Cardoso de Oliveira $(1964,1976,2006)$ presents important questions when it comes to reflections in relation to identity, especially in relation to issues of ethnic-racial conflicts. The concept of "interethnic friction" stands out, which is a time of conflict between identities of different ethnicities and cultures, or when ethnic boundaries are manifested. For example, when groups or people from different cultures manifest their identity characteristics in relation to other groups, an ethnic border becomes evident, and the conflict in these relationships is, for the author, an interethnic friction. The entry of indigenous 
students in public universities can show different moments of friction, whether in the relationship between students, professors, or even between indigenous people of different ethnicities.

Another important reflection made by Cardoso de Oliveira $(1964,1976)$ is related to the concepts of assimilation and acculturation. The assimilation is defined as the social process in which different individuals or groups accept and acquire behavioral patterns, traditions, feelings and attitudes from the other party. It can be said that it is an internal adjustment and an indication of socio-cultural integration when meeting different groups. The concept of acculturation, on the other hand, expresses the overlap of one culture to another, when one of the cultures ceases to exist. In the case of indigenous students, living with different cosmologies within the university may bring new meanings of behavior or understanding for these subjects.

Cardoso de Oliveira $(1964,2006)$ also highlights the concept of ethnocentrism, which can be understood as an emotional attitude that sustains a group, race, ethnicity or society, to which a person belongs, that are supposed to be superior to other racial, social groups, ethnic or cultural. It is associated with contempt for the foreigner or stranger, as well as for their mores. A tool that can serve to prejudice is the stigma, a way of exposing a negative characteristic pejoratively, stereotyping and excluding those who are ethnically "different" (CARDOSO DE OLIVEIRA, 2006). For example, non-indigenous students may despise indigenous students because of their origin and they may doubt the capabilities of the indigenous students, mainly because educational institutions are originally formatted for non-indigenous students.

The structure of universities is surrounded by the interests of dominant elites and was not designed for indigenous people (CUNHA, 1980, 2007; MINOGUE, 1981; CAMACHO, 2005; XERRI, 2012). According to Larkin (2011), neoliberal positivism is impregnated in the Western educational culture, being it a racist epistemology, which reproduces knowledge and ridicules other forms of knowledge, such as the indigenous knowledge.

In this sense, Bodkin-Andrews, O'Rourke, Dillon et al. (2012) point to the need for reorganization of educational institutions, that need to provide conditions and accompany the indigenous students of the university-school, a necessary action to reduce numbers related to dropout and disengagement. According to Estácio and Almeida (2016), in the study about the experience of the state of Amazonas (Brazil) in relation to the reservation of vacancies for indigenous peoples, it is not enough to create vacancies for indigenous people to study at universities, it is also necessary to carry out institutional monitoring, so that the difficulties arising from ethnic-cultural differences are alleviated.

Bouton-Lewis, Wilss and Lewis (2001) present a study that demonstrates that, from the second year at the university, indigenous students become more aware of the learning. This shows, for the universities, that it is necessary to provide an adaptation time for incoming indigenous students, a measure that can help to prevent disengagement and evasion. Still in relation to alternatives to alleviate difficulties and reduce dropouts, Usher, Lindsay and Mackay (2005) and Usher, Miller, Turale et al. (2005) present the alternative of taking the university to the vicinity of the villages, an idea that reduces difficulties related to displacement and financial expenses, and avoids the distancing of the family and the community.

It is found that the entry of indigenous people in higher education and in public universities is not an exclusive concern of the state of Paraná and Brazil. It is added that, outside Brazil, this phenomenon is also evident, for example, in New Zealand. Rakena, Airini and Brown (2016) recognize the presence of indigenous people in the higher education of New Zealand as crossed by two worlds, a western hegemonic worldview and that of an indigenous ethos itself.

In this sense, it was possible to verify that the emergence of indigenous people in universities is complex. The research by Amaral (2010) and other authors (NOVAK, 2007; PAULINO, 2008; CASSANDRE, AMARAL and SILVA, 2016; ANGNES, FREITAS, KLOZOVSKI et al., 2017; AMARAL, FRAGA and RODRIGUES, 2016) demonstrated how complex the indigenous educational path within universities can be. The reflections of Bajada and Trayler (2014) include the training of administrators as an emergency for the experience of indigenous peoples, as also presented in the study by Cassandre, Amaral and Silva (2016). It is necessary to highlight here that, based on the indemnification processes of hydroelectric and railroad undertakings, among others, the indigenous communities start to develop their own productive projects, requiring trained people to manage these businesses that belong to their communities. Thus, academia needs to provide conditions for indigenous people to graduate as managerial professionals, in a manner consistent with the knowledge, cosmologies and expectations of the ethnic groups to which they belong. Amaral (2010) calls the emergence of indigenous professionals graduated and trained in higher education as "new circuit of indigenous intra and (or) inter villages", an expectation of indigenous students who entered universities, as well as their families and their communities. 


\section{The testimonies: the double belonging in the administration course}

The testimonies presented signaled perspectives in three moments, from the points indicated in the script developed for the research: identification; trajectory in the universities; and trajectories and expectations about the world of work.

\section{Identification}

At first, the identification, the existence of dual academic and ethnic-community belonging was perceived and confirmed in the testimony of the indigenous students, who reported frequent daily relationships with family members and with the people of the indigenous lands (living or not in a village), simultaneously with the university experience. The indigenous student Raoni, for example, did not live in the village at the time of the interview, but was born, lived for a long time and maintains close ties with his community, especially with his cousins, uncles and relatives who still live there, and with friends, being evidenced when he said that he goes to the indigenous land to play football and talk with his indigenous relatives.

The fact that Raoni is no longer a resident of indigenous lands does not exclude him from his ethnic group. As mentioned, Barth (1998) already stated that an ethnic group is not static, and that culture, identity and belonging are dynamic and negotiable. Conceptually, an ethnic group is a social organization with members who identify and are identified by others as a category, as a member that belongs to it (BARTH, 1998; CARDOSO DE OLIVEIRA, 2006). In this sense, Raoni affirms his identity and his indigenous belonging, regardless of whether his residence is not on indigenous land. In his report, we can see that, like him, other young indigenous people also left the indigenous lands aiming better working conditions, for study reasons and, sometimes, due to internal conflicts.

It was noted that the belonging of each of the interviewees could have varying levels regarding the characteristics of their ethnic-community belonging in relation to the academic belonging, as in the case of Raoni compared to Yara's, who lives in a village that has no electricity. In this sense, the impact of double belonging or new academic belonging for each indigenous person can have very different degrees of difficulty and adaptation, which directly affects a generalization that can consider the indigenous student as a homogeneous group. Thus, the "arduous" process of coexistence of indigenous students at the university, mentioned by Amaral (2010), can be seen in different measures.

In addition, the environment of each university must be taken into account. Each of Paraná's state universities has a history, size, local and regional characteristics, an administrative structure, reception and permanence policies, student assistance policies and specific institutional characteristics. It is notorious, in Yara's account, the feeling that she has little support at the university, because, according to her, "the institution does not give me any help". Ubirajara is even more specific, stating that, from time to time, someone from CUIA appears to hold a meeting, but he is not accompanied. On the other hand, Niara and Raoni report that the educational institution has closely monitored them since they arrived. The relationships can be very different, also considering the number of indigenous people in each institution and the distance between the indigenous territory and the university. All of this can directly affect possible prejudices and weaknesses in the academic belonging of the indigenous student.

The testimonies showed that there are differences between indigenous and non-indigenous understandings for issues related to daily life, such as hierarchical relationships and knowledge. In addition, all respondents declared that indigenous knowledge and knowledge taught at the university are not equivalent, with Yara and Raoni indicating possible and important connections, and Niara and Ubirajara signaled their total dichotomy. It was also possible to perceive how diverse are the structures on indigenous lands and the indigenous people who belong to them. In the studied group, all were under 30 years old; some were married and had children, others did not; others were single; some spoke the indigenous language and others did not - but all identified themselves as indigenous.

\section{Trajectory in the universities}

In the second moment, regarding the trajectories in universities, we identified that all interviewees mentioned in their initial expectations the interest in acquiring knowledge, but the option for the administration course was expressed in a personal way, that is, each one presented a reason, such as: just the desire to learn, to obtain a "good job" (as reported by Niara) or because it is the option of a course whose access is easier. 
At that moment, the academic belonging to the administration course became evident. Regarding this belonging, when the topic was the difficulties experienced while staying at the university, the transportation and the distance between place of study and home appeared in the report of almost all the witnesses. Problems with electronic and virtual communication were also noticed, since some of them do not have structural resources in their homes, such as internet or even electricity, which may limit, in some way, their participation in extracurricular activities in which there is the need for online research, in situations where professors send study materials over the internet or even communication between classmates. Even so, all of them continue their trajectories in the graduation in administration.

The indigenous students stated that there are incentives to continue studying, being from family members and, in some cases, from the university itself. Yara is specific in saying that "only my mother encourages me, the university does not". Ubirajara, on the other hand, says he seeks motivation in the expectation of getting a job in a public tender when he is graduated.

The relationship with university colleagues (indigenous and non-indigenous), professors and indigenous communities was another topic reported. With the exception of Yara, all of them said that the relationship is very good, either with the university members (students, professors, coordination), or with indigenous people from their villages (leaders, family, community). Yara said that she is very closed, and understands that, perhaps for that reason, the people of the university do not speak much with her, having managed to create friendships with some and have a better relationship only with one professor.

In Yara's account, a notorious prejudice was manifested. In the classroom, when a professor decides to conduct group activities,

we realize that sometimes they avoid us, when we go to do assignments. This year, in the third year, the professor made us not to choose between us, the professor did it like this, number 1, number 2, number 3, then I went with a piá [boy], and the piá said: professor, can't it be changed? These things that happen.

Despite having good relationships with non-indigenous people and not having problems similar to Yara's, Ubirajara confirmed that there is this kind of problem: "there are some who complain that, inside the room, the professor picks on them, the students also when forming a group, when it comes to do assignments. Not with me, thank God".

At this point in the testimonies, Yara and Ubirajara manifested situations that can be alarming: episodes of prejudice. Cardoso de Oliveira $(1964,1976,2006)$ considers that stigma and ethnocentrism are mechanisms that highlight and affirm prejudice, being a stereotype of exclusion from the one that is "different". Yara, more expressly, exposes that she feels the moments when she is not identified and included in the daily relationships with her classmates within the university.

As mentioned in the introduction to this article, the administration course was historically configured in the capitalist context, with origins and influences linked to North American theories. Therefore, the interest of indigenous people in this course may reveal ideological conflicts. On the other hand, scientific research involving intentions, needs, expectations, and indigenous cosmologies can be remarkable alternatives to overcome the paradigm of elitist theories of management. Raoni, in his testimony, said he realized that there is space at the university for indigenous students to develop research related to the interests of their communities. He feels that this depends on a personal and collective interest and that, since he entered the university, however, he has seen little research related in any way to themes that affect indigenous peoples. Niara, from the same university, reported knowing about a study; Yara and Ubirajara have never seen anything like that.

The testimonies reveal the perception that universities have little concern with promoting studies that meet the wishes of indigenous peoples, which may, in some way, demotivate or not guide the needs of these original groups. On the other hand, the existence of supplementary vacancies for indigenous people, such as the one referring to the case of the state of Paraná, still allows for a favorable situation in which indigenous scholars themselves begin to undertake their courses in higher education institutions. In contrast, as presented by several of the authors (AMARAL, 2010; AMARAL, FRAGA and RODRIGUES, 2016; ANGNES, FREITAS, KLOZOVSKI et al., 2017; BODKIN-ANDREWS, O'ROURKE, DILLON et al., 2012; ESTÁCIO and ALMEIDA , 2016), it is not enough to reserve places for the entry of indigenous people, it is also necessary to guarantee an adequate permanence policy, which allows pedagogical monitoring, student assistance, the production of knowledge through research and extension by these subjects in constant relationship with their communities of belonging. It is essential that the presence of indigenous students contributes to interculturalizing higher education and the university (MATO, 2018). 
Regarding the self-assessment of academic performance, all witnessing indigenous students assumed some difficulty. The demand for work emerged as a limiting factor for education performance, as it occupies a lot of time in their daily routines and leaves little space for dedication to studies. It is noteworthy, in Yara's testimony that personal difficulties, with study and work, almost made her drop out of the course, but, even so, she remained studying. Thus, it was seen that the work influences the trajectory of these indigenous students in the universities.

This stage of the testimonies brought to light the understandings, expectations and dilemmas related to the trajectory of the indigenous students that participated in the research in the universities. The aspects that appeared refer to the motivating element of the option for the administration course and the motivations that make them stay in that course. Finally, they started a dialogue about expectations and trajectories about the world of work.

\section{Trajectories and expectations about the world of work}

In this thematic in the testimonies, the first observation concerns the expectations of becoming administrators able to compete for a public job, an interest of many Brazilians, indigenous or not, mainly due to the possibility of a job with stability, which can mean competition from equals with other non-indigenous graduates. In addition, the possibility of indigenous administrators being placed in government agencies, of the Brazilian State, as mentioned by Amaral, Rodrigues and Bilar (2014), can raise the interests of these peoples for public administration. The aforementioned authors analyze the interests of indigenous professionals graduating from Paraná state universities in the management of public bodies important to indigenous lands, such as those in the area of health and education, which may come to mean structural changes not yet seen, starting to to be "protagonists of history and no longer protected" (AMARAL, RODRIGUES and BILAR, 2014, p. 135).

It was also noted that these students were interested in opening a business or company close to indigenous lands. The word business appeared in all the testimonies and the reason may be linked to a characteristic of the formative orientation of the administration course, being a possible peculiarity of an academic belonging in this area of formation. In particular, student Raoni evidenced the need to overcome paternalism and guardianship that the indigenous people historically have, stating that it is necessary to conquer their space and not be tutored, which is a possible influence of the meritocratic vision that the course teaches so much. It may be that this manifestation is the result of what you learned in the course, that the relationships of people should be like that in face of opportunities, but it can also refer to the perspective of autonomy (and not tutelage) historically pursued by indigenous peoples in Brazil.

It was noticed the existence of particular family's expectations regarding the formation of these postulants as administrators, such as "earning well", in the case of Ubirajara, or having a "good profession", as Yara said. With regard to the return of knowledge acquired and socialized in the administration course, for some of them, the gain is professional and can help with personal and family issues. The interviewees did not clearly show how they could articulate the scientific and professional knowledge learned with the traditional knowledge specific to their ethnic groups and their communities, even though epistemological differences and tensions are present.

In any case, it was declared that it would be positive to use much of what they are learning in the course within the village for example, when Raoni says that "public administration in the village [...] would be essential". Ubirajara understands that the knowledge acquired in the administration could also be used to benefit the villages, mainly to take care of projects. However, he reports: "it would be a good thing for us to be able to invest in that. But it doesn't work, a lot of fighting there, it doesn't work". Ubirajara shows his view on the internal conflicts that exist in his indigenous land and the consequences in the application of new knowledge, as well as his legitimacy for that as a member of the community.

Raoni and Ubirajara cite the need for knowledge about public administration and project management as skills learned in the course that can be used in indigenous lands. All of this resumes what was presented by Bajada and Trayler (2014) and Cassandre, Amaral and Silva (2016) regarding the importance of the emergence of the profession of administrator in indigenous lands. However, as well as in communities and non-indigenous groups, it has been reported that, in indigenous lands, there are internal conflicts and factionalisms between family groups that can impede the performance of these new professionals or reduce the use of this knowledge. Such a situation can occur when a chief defines the occupation of jobs in the village and does not consider the importance of undergraduate and graduate students in administration, often because they do not understand the meaning and role of this professional. Such incomprehension can also manifest itself when the administration 
courses are also unaware of the realities of indigenous peoples and their anxieties and needs, disregarding the performance of indigenous professionals in these spaces.

When asked if there is a relationship between knowledge learned at the university and indigenous knowledge, there was unanimity among the interviewees: everyone understands that they are different. The indigenous knowledge was related to the indigenous tradition, customs, culture and the rules of coexistence of the village, "our root", as Ubirajara said. The knowledge learned at the university was linked to the profession and personal growth.

Still regarding the types of knowledge, when asked if the concept of leadership is different for indigenous and non-indigenous communities, it was observed in the testimonies that leadership in the indigenous land is linked to cultural issues, to the dynamism of life in the village and to hierarchy of decisions in that territory. Outside this context, relations were established with government agencies and business organizations. For example, from Ubirajara's perspective, a non-indigenous leader is the person who runs a company and, in Niara's, this type of leadership does not deepen in people's relationships. Raoni says in his testimony that his grandfather, uncle and father were traditional leaders in his village, a descendant of important political leaders in the state, and that the university can contribute to reflect and strengthen his leadership memory or erase and hide it, according with the concepts of leaderships (business, managerial) that dispute the formation of the administrator.

In labor relations, Niara and Raoni demonstrated a feeling that non-indigenous people look at them, in the profession, with a little fear, that is, they suspect their intentions and competence, as stated Niara: "at work, the indigenous administrator, like this, finds it difficult if sometimes like this [...], in a work environment that I would work, people can look at you differently (compared to the looking at non-indigenous people)". Raoni was more emphatic when he stated: "I think that [...] society expects more from you, because you are different, because you are an Indigenous, if expect a little more, it is as if they said: 'I want to see what comes out of there "'.

As for the expectation of what it is (or will be) to be an indigenous administrator, Kaingang or Guarani, for Ubirajara and Niara there is no difference in relation to a non-indigenous administrator. Raoni understands that he is a representative of his people who "will stand out for persistence, for defending what he believes, his values and his ethics [...] I want to make a difference!" Yara showed a feeling that "Guarani administrator is proud. There are several who are not indigenous who wanted to be here in my place. I had this opportunity, I passed the indigenous entrance exam, many wanted to be here, but I am". Thus, everyone shows the expectation of what it is to be an indigenous administrator.

The understandings, expectations and dilemmas of the indigenous students of the administration course were represented in the testimonies as predicted the objective of this research. It was noted, in this topic, that the witnesses expressed their conceptions about the trajectories in the universities and trajectories and expectations about the world of work, which allowed the effectiveness of the present study.

The testimonies presented represent the perceptions of each indigenous student who participated freely in this study. Together, these perceptions can convey the idea of how diverse indigenous peoples are and, thus, help to perceive issues hitherto unknown to them and to the area of administration.

\section{FINAL CONSIDERATIONS}

The reflections presented in this article were circumscribed around the dual belonging of indigenous students - academic and ethnic-community -, seeking to understand the existence of simultaneous experiences of these subjects between the university and their communities of belonging. In this research, the interpretation focuses on the phenomenon related to the trajectories of indigenous students in administration courses, relating them in a dialectical way, at all times, with the dimensions related to the daily lives of these subjects and to the macro-social issue. Thus, the meaning of double belonging, in this study, can be understood in another guise, if seen in the strict sense: ethnic-community belonging and belonging to the administration course, simultaneously.

The testimonies also indicated the existence of a desire to apply the knowledge acquired at the university in the indigenous lands, which may be a paradox for the current demand for administrator training, if the curricula of the administration courses are not properly contextualized to the indigenous realities. In this sense, this study contributes to problematize this conflict 
in the demand for teaching and learning in administration and to give new contours to debates related to the meaning of the course, with the inclusion of the indigenous people as interested in this education.

The presence of indigenous students in administration courses can represent a statement regarding the struggles waged over the years by different indigenous peoples in Brazil and Latin America. They carry, in their personal characteristics, their knowledge, their histories, their culture, being able to raise and postulate their understandings for the university and for the administration course. The understandings, expectations and dilemmas experienced by them in relation to their formative path were represented, in this research, in their testimonies.

With regard to their trajectory at universities, indigenous students exposed difficulties that they face daily during the school year, some due to structural limitations for study in their communities, such as lack of internet, or even the weakness in the basic education of indigenous students resulting from their schooling path, compared to cultural capital or the educational background of other non-indigenous students. Yara's shyness may be related to the insufficient repertoire in schooling to accompany debates and tasks in the academic environment, added to the prejudices existing in professors and classmates. This can transform the journey of double belonging into moments of suffering, given the feeling of exclusion from peers at the university. This is a need to be seen by the faculty of the administration courses: the creation of spaces and moments of approximation, reflection and interculturality with the epistemologies and indigenous realities, in order to avoid moments of embarrassment, as reported in Yara's testimony.

As for the trajectories and expectations about the world of work, indigenous students, like many other Brazilian students, need to work and study simultaneously, having reduced time to study at home. Another complicating factor for indigenous students is the matter of displacement and the distance between the university and the indigenous lands, which, in all reports, appeared as a difficulty, especially when considering the issue of physical exhaustion at the end of each day of study-job. In addition, it was observed that some of them have children and a family, which requires even more attention.

Among the dilemmas highlighted, we highlight the existence of personal and private expectations - often fostered by the individualistic and meritocratic orientation of administration courses - and the collective and community dimension of indigenous peoples and communities. In this sense, there is a question that can serve as inspiration for other research projects: what will be the professional insertion of the new indigenous administrators and what will be the return of the acquired knowledge to the indigenous communities, given the original meaning that guides this formation? The constitution of new indigenous work circuits, as analyzed by Amaral (2010), can change the logic and dynamics of organizations active in indigenous lands, and mobilize and reconfigure power relations within communities, with the role of indigenous administrators.

What is it to be an indigenous administration student? The question in the title of this article cannot be answered in a linear way, in view of the complexity of indigenous communities, universities and the indigenous subject himself, marked by identities and belongings. However, it was found that to be an academic of indigenous administration is to be in a constant struggle to assert oneself and remain studying, due to the structural factors of the universities, which were not thought and planned for the indigenous peoples. Furthermore, it is in conflict with the culture and hierarchical structure of the villages, which may reject the use of non-indigenous knowledge, fundamentally from the administration area, in their territories, often because they are unaware of this area or even because they consider it irrelevant for its traditional way of being and organizing.

In this sense, it is understood that being an indigenous student in administration requires taking a mediating action pointing out academic knowledge in the area of administration that can assert the role and autonomy of their communities of belonging and, at the same time, point out the fundamental indigenous traditional knowledge that can be known and appropriated by administration courses.

Finally, it must be stated that this article was intended to enable the free expression of indigenous students, future administrators. It also had the objective of provoking the elaboration of new researches that can help the trajectories of other indigenous students in the administration course. 


\section{REFERENCES}

AMARAL, W. R. do. As trajetórias dos estudantes indígenas nas universidades estaduais do Paraná: sujeitos e pertencimentos. 2010. Doctoral Dissertation (Doctor Degree in Education) - Universidade Federal do Paraná, Curitiba, 2010.

AMARAL, W. R. do; RODRIGUES, M. A.; BILAR, J. A. B. Os circuitos de trabalho indígena: possibilidades e desafios para acadêmicos e profissionais Kaingang na gestão das políticas públicas. Mediações, Londrina, v. 19, n. 2, p. 129-145, July/Dec. 2014.

AMARAL, W. R. do; CASSANDRE, M. P.; PAULA, L. A. Eu, Luciane, da etnia Kaingang: o testemunho de uma assistente social indígena e seu duplo pertencimento. In: I CONGRESSO INTERNACIONAL DE POLÍTICA SOCIAL E SERVIÇO SOCIAL: DESAFIOS CONTEMPORÂNEOS, 1., 2015, Londrina. Anais... Londrina: [s.n.], 2015.

AMARAL, W. R. do; FRAGA, L.; RODRIGUES, I. C. Universidade para indígenas a experiência do Paraná. Rio de Janeiro: FLACSO, GEA; UERJ, LPP, 2016.

ANGNES, J. S.; FREITAS, M. F. Q. de; KLOZOVSKI, M. L.; COSTA, Z. da F.; ROCHA, C. M. A permanência e a conclusão no ensino superior: O que dizem os Índios da Universidade Estadual do Centro Oeste do Paraná (UNICENTRO) - Brasil. Arquivos Analíticos de Politicas Educativas, v. 25, n. 6, 2017.

BAJADA, C.; TRAYLER R. A fresh approach to indigenous business education. Australia: Emerald Group Publishing Limited, 2014.

BARTH, F. Grupos étnicos e suas fronteiras. Bergen, Oslo: Universitetsforlagets, 1969. In: POUTIGNAT, P.; STREIFF-FENART, J. Teorias da etnicidade. Seguido de grupos étnicos e suas fronteiras de Fredrik Barth. São Paulo: Fundação Editora da UNESP, 1998.

BERNAL, D. D.; BURCIAGA, R.; CARMONA, J. Chicana/Latina testimonios: mapping the methodological, pedagogical, and political. Equity \& Excellence in Education, v. 45, n. 3, p. 363-372, 2012.

BODKIN-ANDREWS, G. H.; O'ROURKE, V.; DILLON, A.; CRAVEN, R. G.; YEUNG, A. S. Engaging the disengaged?: a longitudinal analysis of the relations between Indigenous and non-Indigenous Australian students' academic self-concept and disengagement. Journal of Cognitive Education and Psychology, v. 11, n. 2, 2012.

BOUTON-LEWIS, G. M.; WILSS, L.; LEWIS, D. C. Changes in conceptions of learning for indigenous Australian university students. British Journal of Educational Psychology, v. 71, p. 327-341, 2001.

CAMACHO, T. A universidade pública no Brasil. Revista Mexicana de Sociologia, Santiago do Chile, v. 19, n. 1, p. 101-132, 2005.

CAPELO, M. R. C.; TOMMASINO, K. Conflitos e dilemas da juventude indígena no Paraná: escolarização e trabalho como acesso à modernidade. Cadernos CERU, São Paulo, n. 15, 2004.

CARDOSO DE OLIVEIRA, R. Caminhos da identidade: ensaios sobre etnicidade e multiculturalismo. São Paulo; Brasília: Editora da Unesp; Paralelo 15, 2006.

CARDOSO DE OLIVEIRA, R. Identidade, etnia e estrutura social. São Paulo: Pioneira, 1976.

CARDOSO DE OLIVEIRA, R. O índio e o mundo dos brancos. Brasília: Editora da UnB, 1964.
CARVALHO, M. L. B. de. Das terras dos índios a índios sem terras. O Estado e os Guarany do Oco'y. Violência, silêncio e luta. 2013. 835p. Doctoral Dissertation (Doctor Degree in Geography) - Programa de Pós-Graduação em Geografia Humana, Departamento de Geografia da Faculdade de Filosofia, Letras e Ciências Humanas, Universidade de São Paulo, São Paulo, 2013.

CASSANDRE, M. P.; AMARAL, W. R.; SILVA, A. Eu, Alex, da etnia Guarani: o testemunho de um estudante indígena de administração e seu duplo pertencimento. Cadernos EBAPE.BR, Rio de Janeiro, v. 14, n. 4, out./dez. 2016.

CUNHA, L. A. A universidade crítica: o ensino superior na república populista. 3. ed. São Paulo: Editora da UNESP, 2007.

CUNHA, L. A. A universidade temporã. 2. ed. Rio de Janeiro: Francisco Alves, 1980.

ESTÁCIO, M. A. F.; ALMEIDA, D. A. R. Indigenous in the Universidade do Estado do Amazonas. Journal of Research in Special Educational Needs, v. 16, 2016.

LARKIN, S. Indigenous Perspectives Enriching Scholarship. Australia: Australian Social Work, 2011.

MATO, D. Educação superior e povos indígenas: experiências, estudos e debates na América Latina e em outras regiões do mundo. Revista de Estudos e Pesquisas sobre as Américas, Brasília, v. 12, n. 3, 2018.

MINOGUE, K. O conceito de universidade. Brasília: Editora da UnB, 1981.

NOVAK, M. S. J. Política de ação afirmativa: a inserção dos indígenas nas Universidades Públicas Paranaenses. Maringá, PR: UEM, 2007.

OLIVEIRA, A. L. de; LOURENÇO, C. D. da S.; CASTRO, C. C. de. Ensino de administração nos EUA e no Brasil: evidências de um ensino com problemas. In: ENCONTRO NACIONAL DA ASSOCIAÇAO NACIOAL DE PÓS-GRADUAÇÃO EM PESQUISA EM ADMINISTRAÇÃO, 37, 2013, Rio de Janeiro. Anais... Rio de Janeiro: EnANPAD, 2013.

PAULINO, M. M. Povos indígenas e ações afirmativas: o caso do Paraná. 2008. 168f. Master Thesis (Master Degree in Education) Universidade Federal do Rio de Janeiro, Rio de Janeiro, 2008.

PACHECO DE OLIVEIRA, J.; FREIRE, C. A. da R. A presença indígena na formação do Brasil. Brasília: MEC/SECAD, LACED; Museu Nacional, 2006.

RAKENA, T. O.; AIRINI; BROWN, D. Success for all: eroding the culture of power in the one-to-one teaching and learning context. International Journal of Music Education, v. 34, n. 3, 2016.

USHER, K.; LINDSAY, D.; MACKAY, W. An innovative nurse education program in the Torres Strait Islands. Nurse Education Today, v. 25, n. 6, 2005.

USHER, K.; MILLER, M.; TURALE, S.; GOOL D, S. Meeting the challenges of recruitment and retention of Indigenous people into nursing: outcomes of the Indigenous Nurse Education Working Group. Collegian, v. 12, n. 3, 2005.

XERRI, E. G. Breve incursão à história das universidades. In: ALBECHE, D. L. (Org.). Universidade e sociedade: visões de um Brasil em construção. Caxias do Sul: Educs, 2012. 
Renan Carlos Klichowski

ORCID: https://orcid.org/0000-0003-1113-8614

Master in Business Administration from the State University of Maringá (UEM), Maringá- PR, Brazil.E-mail: renan.kli@outlook.com

Marcio Pascoal Cassandre

ORCID: https://orcid.org/0000-0001-9415-4315

$\mathrm{PhD}$ in Administration from Positivo University with sandwich period from University of Helsinki; Adjunct professor in the Graduate Program in Administration at the State University of Maringá (PPA/UEM), Maringá- PR, Brazil. E-mail: mpcassandre@uem.br

Wagner Roberto do Amaral

ORCID: https://orcid.org/0000-0002-8555-5915

PhD in Education from the Federal University of Paraná (UFPR); Adjunct professor in the Graduate Program in Social Work and Social Policy at the State University of Londrina (UEL), Londrina-PR, Brazil. E-mail: wramaral2011@hotmail.com 